\title{
Immunogenetic Heterogeneity in Single-System and Multisystem Langerhans Cell Histiocytosis
}

\author{
CECILIA BERNSTRAND, HENRIK CARSTENSEN, BODIL JAKOBSEN, ARNE SVEJGAARD, \\ JAN-INGE HENTER, AND OLLE OLERUP
}

\author{
Childhood Cancer Research Unit, Astrid Lindgren Children's Hospital, Karolinska Hospital, Karolinska \\ Institutet, S-171 76 Stockholm, Sweden [C.B., J.-I.H.]; Departments of Pediatrics [H.C.] and Clinical \\ Immunology [B.J., A.S.], Rigshospitalet, Blegdamsvej 9, DK-2100 Copenhagen, Denmark; and Department \\ of BioSciences, Karolinska Institutet, Novum and Division of Clinical Immunology, Huddinge University \\ Hospital, S-141 57 Huddinge, Sweden [O.O.]
}

\begin{abstract}
ABSTR
Langerhans cell histiocytosis is a rare disease with an un-
known etiology and poorly understood pathogenesis. Immuno-
logic, viral, and proliferative clonality causes have all been
considered. To determine whether Langerhans cell histiocytosis
and its two main subgroups, single-system and multisystem
disease, are associated with HLA-A, -B, -Cw, or -DR alleles, a
total of 84 patients $<15$ y of age at the time of diagnosis and of
Nordic origin were analyzed, 82 for HLA class I and 76 for HLA
class II. Stratification of the patients into two subgroups, single-
system disease (skin only, and monostotic and polyostotic dis-
ease) and multisystem disease with or without organ dysfunction,
showed that patients with single-system disease (17 of $45,38 \%)$
more often $(p=0.00018$ and, after correction, $p=0.029)$ had
the phenotype $H L A-D R B 1 * 03$ compared with patients with mul-
tisystem disease $(1$ of $31,3 \%)$. In the patients with multisystem
disease a nonsignificant reduction of the frequency of this phe-
\end{abstract}
notype was seen compared with controls ( $p=0.02$, uncorrected). In 14 of the patients with single-system disease, but none with multisystem disease, the deduced haplotype $H L A-A^{*} 01, B * 08$, $D R B 1 * 03$ was found. High-resolution typing, performed in nine patients, revealed that all had the $H L A-A^{*} 0101, B^{*} 0801$, $D R B 1 * 0301, D Q B 1 * 0201$ alleles. Our findings suggest an immunogenetic heterogeneity in the two clinical entities of Langerhans cell histiocytosis and indicate that $H L A-D R B 1^{*} 03$ may play a protective role against developing multisystem disease. Further studies to confirm these findings are desired. (Pediatr Res 54: 30-36, 2003)
Abbreviations
LCH, Langerhans cell histiocytosis
SSP, sequence-specific primers

$\mathrm{LCH}$, previously known as histiocytosis $\mathrm{X}$, eosinophilic granuloma, Hand-Schüller-Christian, or Letterer-Siwe disease, is a rare disease with a reported incidence in childhood of 5.4 cases per million children per year (1). It is characterized by an accumulation or proliferation of abnormal and clonal Langerhans cells in various organs such as the skin, bone, lymph nodes, lungs, liver, spleen, and bone marrow (2-6). The disease can present at any age although young children are most often affected. The course of the disease is unpredictable, varying from a spontaneously healing isolated bone or skin lesion to a chronic relapsing course resulting in permanent

Received June 4, 2002; accepted November 4, 2002.

Correspondence: Cecilia Bernstrand, M.D., Ph.D., Childhood Cancer Research Unit, Q6:05, Karolinska Hospital, S-171 76 Stockholm, Sweden; e-mail: Cecilia.Bernstrand@kbh.ki.se

Supported by the Children's Cancer Foundation of Sweden, the Swedish Medical Research Council 10393 (O.O.), 11953 (O.O.), 12240 (J.-I.H.), the Märta and Gunnar V Philipson Foundation, the Cancer Foundation of Sweden, and the Mary Béve Foundation. This study was presented in part at the Seventeenth Annual Meeting of the Histiocyte Society in Stresa, Italy, 2001.

DOI: $10.1203 / 01 . P D R .0000069844 .50684 .7 D$ consequences or to a multiorgan disease that can be fatal (7). The histopathologic features of each form of LCH are highly similar, but it is not yet known whether these two manifestations of the disease have a common cause or whether each has a separate and distinct initial cause (6).

The etiology of LCH is unknown, and immunologic, viral, and proliferative clonality have all been considered (6). The disease is usually regarded as a nonhereditary disorder, but a recent report of familial clustering of LCH cases could support a role of genetic (or environmental) factor(s) in LCH (8). In a large case-control study conducted in North America, an association was found between LCH and thyroid disease as well as a family history of thyroid disease (9). These findings imply that there may be both a hereditary and an (auto)immune genesis to $\mathrm{LCH}$, but despite the apparent involvement of the immune reactions an autoimmune origin of $\mathrm{LCH}$ has never been proved.

The HLA genes that are involved in the immune response express molecules that fall into two classes. Class I molecules are expressed on the cell surface of most nucleated cells, 
whereas class II molecules are mainly expressed on cells of the immune system, such as macrophages, B cells, and dendritic cells $(10,11)$. The normal Langerhans cell belongs to the dendritic antigen-presenting cells expressing both class I and II molecules (12). Interestingly, in LCH the antigen-presenting functional capacity of Langerhans cells seems to be greatly reduced (3).

The HLA allelic polymorphism determines the immune response phenotype of an individual and thus has a major influence on resistance against infections and may also be able to influence the progress of cancer (13). The allelic and haplotype frequencies vary in different populations, which partly explains the variation in occurrence of HLA-associated diseases among different ethnic groups (14). A large number of diseases are associated with specific class I or class II alleles (15). In some diseases, the responsible genes are in linkage disequilibrium with the HLA loci, but in other diseases such as ankylosing spondylitis, the class I and class II genes themselves may be involved. In particular, several diseases with autoimmune features are considered to be primarily associated with alleles of the HLA class II region $(10,11,13,15-17)$.

Previous studies on the frequencies of specific HLA types in patients with histiocytosis have usually been limited by the small number of patients, study groups consisting of mixed ethnic origins, or analysis with serologic typing techniques $(18-21)$.

The aim of this study was to determine whether there is an association with HLA-A, -B, -Cw, or -DR and LCH, and the single-system and multisystem disease subgroups of $\mathrm{LCH}$. The study was conducted on a relatively large and ethnically homogeneous group of patients.

\section{METHODS}

\section{Patients}

All patients and controls included in this study were Caucasians of Nordic origin. The disease classification was based on the diagnostic evaluation at the time of diagnosis. We have used the following categories in the classification of organ involvement: single-system disease including skin disease only, monostotic disease (one bone lesion), and polyostotic disease (two or more bone lesions but no other organ involvement); and multisystem disease (two or more organs involved including endocrine deficiencies) with or without organ dysfunction according to Lahey's criteria (22). We defined disease outcome at the time of HLA typing as either active disease (the patient had persistent symptoms or was on LCH therapy), inactive disease (no symptoms), or death owing to $\mathrm{LCH}$ or its treatment. The study was approved by the Ethical Review Committee at the Karolinska Hospital and was conducted with informed consent.

The Swedish group of patients. Patient characteristics are shown in Table 1. There were 54 unrelated children $\leq 15$ y $(28$ boys, 26 girls) with a median age at diagnosis of 2.6 y (range, $0.2-14.8 \mathrm{y}$ ). The patients included in this study were all living in Sweden and are of Nordic origin. Forty-nine patients had been referred to the Department of Pediatrics at the Karolinska Hospital in Stockholm between July 1962 and October 2000, and five patients had been diagnosed at the University Hospital of Umeå. Sixteen patients, diagnosed at the Karolinska Hospital, were excluded because of other ethnic origin. Paraffinembedded histologic samples and cytologic specimens from all patients were reviewed and confirmed to be consistent with $\mathrm{LCH}$ according to recent classification criteria (23). Forty-four patients had a definitive and 10 a presumptive diagnosis of LCH. Seven of the patients with a presumptive diagnosis had been diagnosed with fine-needle aspiration biopsy, most of them before 1990 when immunology staining for CD1a was not yet a routine procedure. In the other three patients biopsies of bone lesions revealed a typical morphology, but staining was negative for CD1a with the O10 anti-CD1a antibody. The negative immunoreactivity was probably caused by decalcification of the bone before processing for histology. Frozen blood samples from the Swedish group of LCH patients have been analyzed by genomic typing (mainly analyzed by $\mathrm{C}$. Bernstrand). Fifty-two patients have been analyzed for HLA-A, -B, and -Cw, and 54 patients for HLA-DR. The

Table 1. Patient characteristics at the time of diagnosis

\begin{tabular}{|c|c|c|c|c|c|}
\hline & $\begin{array}{l}\text { Stage at } \\
\text { diagnosis } \\
(n)\end{array}$ & $\begin{array}{c}\text { Sex M:F } \\
(n)\end{array}$ & $\begin{array}{l}\text { Age at diagnosis (y) } \\
\text { mean/median/range }\end{array}$ & $\begin{array}{c}\text { Age at last } \\
\text { follow-up (y) } \\
\text { mean/median/range }\end{array}$ & $\begin{array}{c}\text { Disease outcome } \\
\text { inactive/active/death } \\
(n)\end{array}$ \\
\hline \multicolumn{6}{|l|}{ Swedish children } \\
\hline SS, skin & 3 & $3: 0$ & $1.0 / 0.5 / 0.3-2.1$ & 7.7/8.1/3.0-12.0 & $3 / 0 / 0$ \\
\hline SS, polyostotic & 4 & $2: 2$ & $5.2 / 3.6 / 1.7-12.0$ & $11.5 / 10.0 / 7.2-18.7$ & $4 / 0 / 0$ \\
\hline MS, no organ dysfunction & 16 & $10: 6$ & $3.2 / 2.0 / 0.4-11.8$ & $15.2 / 12.3 / 1.2-35.5$ & $13 / 3 / 0$ \\
\hline \multicolumn{6}{|l|}{ Danish children } \\
\hline SS, monostotic & 4 & $1: 3$ & 6.6/7.6/0.4-10.8 & $13.8 / 15.7 / 6.2-18.0^{*}$ & $10 / 0 / 0^{*}$ \\
\hline SS, skin & 6 & $5: 1$ & $0.7 / 0.5 / 0.2-1.4$ & $13.8 / 15.7 / 6.2-18.0^{*}$ & $10 / 0 / 0^{*}$ \\
\hline SS, polyostotic & 5 & $3: 2$ & $1.9 / 1.9 / 1.5-2.3$ & $13.5 / 14.1 / 9.3-18.0$ & $5 / 0 / 0$ \\
\hline MS, no organ dysfunction & 8 & $6: 2$ & 2.6/1.4/0.3-12.0 & $15.4 / 15.2 / 2.1-25.4$ & $8 / 0 / 0$ \\
\hline MS, organ dysfunction & 7 & $5: 2$ & $3.4 / 2.0 / 0.4-9.2$ & $10.8 / 14.8 / 0.5-18.5$ & $3 / 0 / 4$ \\
\hline
\end{tabular}

* Combined follow-up data for the groups SS monostotic and skin.

SS, single-system disease; MS, multisystem disease. 
control group consisted of 150 blood donors and 100 cadaveric donors selected randomly.

The Danish group of patients. Patient characteristics are shown in Table 1. There were 30 unrelated Danish children included in the study ( 20 boys, 10 girls) with a median age at diagnosis of $1.5 \mathrm{y}$ (range, $0.2-12.0 \mathrm{y}$ ). All children had a definitive diagnosis based on CD1a-positivity or presence of Birbeck's granules. They were all diagnosed and treated at Rigshospitalet in Copenhagen between August 1966 and March 1999. HLA analyses were performed randomly in patients with LCH at the Department of Tissue-typing and Immunology of Rigshospitalet by serology. Thirty patients have been analyzed for HLA-A and -B, and 22 patients for HLADR. The control group consisted of blood donors and healthy, unrelated Danish individuals, including a total of 1967 controls for class I and 704 controls for class II (24).

\section{Experimental Methods}

HLA typing can be performed using different techniques. Conventional serologic and cellular typing methods permit identification of the HLA class I and II alleles. However, in some cases reliable assignment of class I and II alleles is impossible because of the small number or poor quality of $\mathrm{T}$ or B cells, or the reduced expression of HLA molecules on the cell surface. Genomic HLA typing using PCR-based typing methods has been shown to be accurate in HLA-association studies $(25,26)$. The polymorphism detected with PCR-based typing methods correlates well with the polymorphism recognized by serology and cellular typing (27). More importantly, with DNA-based tissue typing, more biologically relevant polymorphisms may be detected with error frequencies lower than with serology $(28,29)$.

\section{Genomic Typing Technique Used To Analyze the Swedish Group of Patients}

DNA extraction. Whole peripheral blood samples anticoagulated with anhydric citric acid (ACD) $(5 \mathrm{~mL})$ were drawn and deep-frozen $\left(-20^{\circ} \mathrm{C}\right)$ pending analysis. High molecular weight DNA was extracted by salting-out in mini-scale (30).

PCR amplification primers. HLA-A, - $\mathrm{B},-\mathrm{CW}$, and -DR typing was performed by PCR amplification using SSP. Twenty-four PCR-SSP reactions for HLA-A, 48 for HLA-B, 23 for HLA-Cw, and 24 for HLA-DR were performed giving a resolution corresponding to high-quality serologic typing, i.e. defining the HLA alleles according to the first two digits in the allele designation (27). Subtyping for HLA-A*01, B*08, $\mathrm{CW}^{*} 07, \mathrm{DRB} 1 * 03$, and DQB1*02 was performed with PCR typing technique. Eight PCR-SSP reactions were performed for HLA-A*01, 16 for $\mathrm{B}^{*} 08,16$ for $\mathrm{Cw}^{*} 07,16$ for $\mathrm{DRB} 1 * 03$, and 4 for $\mathrm{DQB} 1 * 02$, giving a complete high resolution.

PCR reaction mixtures. Each PCR reaction mixture contained two to three allele- or group-specific primers, and an internal positive-control primer pair. The PCR reaction mixtures $(10 \mu \mathrm{L})$ consisted of $60 \mathrm{ng}$ of genomic DNA, PCR buffer [50 mM KCl, $1.5 \mathrm{mM} \mathrm{MgCl}_{2}, 10 \mathrm{mM}$ Tris-Cl, $\mathrm{pH} 8.3,0.01 \%$ (wt/vol) gelatin], $200 \mu \mathrm{M}$ each dATP, dCTP, dGTP, and dTTP, $0.25 \mu \mathrm{M}$ allele- and group-specific primers, $0.05 \mu \mathrm{M}$ control primers, $0.40 \mathrm{U}$ of $\mathrm{Taq}$ polymerase (Amersham Pharmacia Biotech), and 5\% (vol/vol) $99.5 \%$ glycerol and cresol red sodium salt $(100 \mathrm{mg} / \mathrm{mL})$.

PCR cycling factors. Thirty amplification cycles were performed in a GeneAmp PCR System 9600 (Perkin-Elmer Cetus Instruments). An initial denaturation cycle of $2 \mathrm{~min}$ at $94^{\circ} \mathrm{C}$, followed by 10 cycles with denaturation for $10 \mathrm{~s}$ at $94^{\circ} \mathrm{C}$ and a combined annealing-extension step at $65^{\circ} \mathrm{C}$ for $60 \mathrm{~s}$, was then followed by 20 cycles with denaturation for $10 \mathrm{~s}$ at $94^{\circ} \mathrm{C}$, an annealing temperature of $61^{\circ} \mathrm{C}$ for $50 \mathrm{~s}$, and an extension step at $72^{\circ} \mathrm{C}$ for $30 \mathrm{~s}$.

Agarose gel electrophoresis. The absence or presence of PCR products was visualized by agarose gel electrophoresis. PCR reaction mixtures were loaded into 3-mm-wide slots in 2\% (vol/vol) Moderate Electroendomosis (ME) agarose gels (SeaKem, FMC BioProducts) prestained with ethidium bromide $(0.5 \mu \mathrm{g} / \mathrm{mL}$ gel $)$. Gels $(20 \times 20 \mathrm{~cm})$ were run for $15 \mathrm{~min}$ at $10 \mathrm{~V} / \mathrm{cm}$ in $0.5 \times$ TBE buffer $(89 \mathrm{mM}$ Tris base, $89 \mathrm{mM}$ boric acid, 2 mM EDTA, pH 8.0) without buffer recirculation. Gels were examined under UV illumination and photographed.

\section{Serological Typing Technique Used To Analyze the Danish Group of Patients}

Tissue-typing of HLA class I (HLA-A, -B) antigens. From a blood specimen (fresh blood $<24 \mathrm{~h}$ ) a T-lymphocyte suspension was produced using immunomagnetic beads covered with anti-CD8. The cells were then isolated by means of a magnet, washed, and incubated in a microchamber with known antibodies. Subsequently, complement was added along with a color that identifies dead cells. Cells were observed using a converted fluorescence microscope (31).

Tissue-typing of HLA class II (HLA-DR) antigens. A B-lymphocyte suspension was made from a blood specimen by means of immunomagnetic beads covered with monomorphic anti-class II antibodies. The cells were isolated using a magnet, washed, and incubated in microchambers with known antibodies. Complement was added, and a color mixture including acridine orange, which colors living cells, and ethidiumbromide, which colors dead cells, was used. Cells were observed using a converted fluorescence microscope.

\section{Statistical Analysis}

The $\chi^{2}$ test was used for comparison of frequencies. When the total number of expected observations was fewer than five in any stratum, Fisher's exact test was used. Correction for multiple comparisons was made.

\section{RESULTS}

We have stratified the disease into the two main subgroups, single-system disease (skin only, monostotic, and polyostotic disease) and multisystem disease with or without organ dysfunction. This stratification was done because the multisystem variant of the disease is considered to be more aggressive with a poorer outcome (32).

The Swedish group of 54 patients and 250 controls was analyzed for the frequencies of HLA-A, -B, -Cw, and -DR 
specificities using PCR amplification with SSP. Fifty-two Swedish patients were analyzed for HLA-A, -B, and -Cw, and 54 patients for HLA-DR (Tables 2-4). The Danish group of 30 patients and 1967 controls was studied for the frequencies of HLA-A, -B, and -DR specificities using serologic typing techniques. Thirty Danish patients have been analyzed for HLA-A and -B, and 22 patients for HLA-DR (Tables 2-4).

HLA-Cw was determined in the Swedish group of patients only and with genomic typing technique (data not shown). The phenotype frequencies overall did not differ from the controls. The most common phenotype in the patients $(65 \%)$ as well in the controls (54\%) was Cw7.

No HLA association was found in the total patient population. However, stratification into single-system and multisystem disease revealed that the patients with single-system disease ( 17 of $45,38 \%$ ) had the phenotype $D R B 1 * 03$ more often compared with both the patients with multisystem disease (1 of $31,3 \%)$ and the controls ( $17 \%$ and $24.7 \%$, Swedish and Danish controls, respectively; Table 5). The comparison between the two patient groups was significant $(p=0.00018$ and, after correction, $p=0.029$ ). Furthermore, a nonsignificant decrease of the frequency of this phenotype was found in the patients with multisystem disease compared with the controls $(p=$ 0.02 , uncorrected). In 14 of the patients with single-system disease, but in none with multisystem disease, the deduced haplotype $H L A-A^{*} 01, B^{*} 08, D R B 1^{*} 03$ was found (Table 5). High-resolution typing, performed in nine of the 14 patients, revealed that all had the $H L A-A^{*} 0101, B^{*} 0801, C w^{*} 0701$, $D R B 1 * 0301, D Q B 1 * 0201$ alleles (Table 5).

\section{DISCUSSION}

In the present study, the distributions of the HLA-A, $-\mathrm{B},-\mathrm{Cw}$, and -DR alleles were determined in 84 Nordic patients with a diagnosis of LCH. Eighty-two patients were analyzed for HLA class I, and 76 patients, for HLA class II. Our results suggest an immunogenetic heterogeneity within the two clinical entities of LCH: the patients with single-system disease more often had the phenotype $H L A-D R B 1 * 03$ compared with the patients with multisystem disease ( $p=0.00018$ and, after correction, $p=0.029$ ), and a nonsignificant reduction of the $D R B 1 * 03$ phenotype frequency was seen in the patients with multisystem disease compared with the controls ( $p=0.02$, uncorrected). Furthermore the deduced haplotype $H L A-A^{*} 01, B^{*} 08, D R B 1^{*} 03$ was found in 14 patients with single-system disease and in none with multisystem disease. The stratification was done because the multisystem variant of the disease is considered to be more aggressive with a poorer outcome (32), which is also in line with our own results in a recent long-term follow-up study that indicates a survival in multisystem disease of $77 \%$ compared with $100 \%$ in patients with $\mathrm{H}$ single-system disease (Bernstrand $\mathrm{C}$, et al., manuscript in preparation).

There have been few earlier reports about HLA typing in patients with $\mathrm{LCH}$. Investigators from the United Kingdom found no HLA association in 12 serologically typed patients, with various organ involvement, compared with 150 controls (18). However, this result is difficult to interpret because of the small number of patients. In a Japanese study, an increased frequency of HLA-Bw61 and -Cw7 was found in 35 patients

Table 2. Phenotype frequencies of HLA-A allelic groups in patients with Langerhans cell histiocytosis compared with controls

\begin{tabular}{|c|c|c|c|c|c|c|c|c|c|c|c|}
\hline \multirow[b]{2}{*}{ HLA-A* } & \multicolumn{4}{|c|}{ Swedish group (genomic typing technique) } & \multicolumn{4}{|c|}{ Danish group (serologic typing technique) } & \multicolumn{3}{|c|}{ Total } \\
\hline & $\begin{array}{c}\text { Patients with } \\
\text { stage SS } \\
(n=32) \\
(\%)\end{array}$ & $\begin{array}{c}\text { Patients with } \\
\text { stage MS } \\
(n=20) \\
(\%)\end{array}$ & $\begin{array}{c}\text { All } \\
\text { patients } \\
(n=52) \\
(\%)\end{array}$ & $\begin{array}{c}\text { Controls } \\
(n=250) \\
(\%)\end{array}$ & $\begin{array}{c}\text { Patients with } \\
\text { stage SS } \\
(n=15) \\
(\%)\end{array}$ & $\begin{array}{c}\text { Patients with } \\
\text { stage MS } \\
(n=15) \\
(\%)\end{array}$ & $\begin{array}{c}\text { All } \\
\text { patients } \\
(n=30) \\
(\%)\end{array}$ & $\begin{array}{c}\text { Controls } \\
(n=1967) \\
(\%)\end{array}$ & $\begin{array}{c}\text { Patients with } \\
\text { stage SS } \\
(n=47) \\
(\%)\end{array}$ & $\begin{array}{c}\text { Patients with } \\
\text { stage MS } \\
(n=35) \\
(\%)\end{array}$ & $\begin{array}{c}\text { All } \\
\text { patients } \\
(n=82) \\
(\%)\end{array}$ \\
\hline$* 01$ & 31 & 20 & 27 & 27 & 47 & 13 & 30 & 32 & 36 & 17 & 28 \\
\hline$* 02$ & 66 & 65 & 60 & 59 & 47 & 73 & 60 & 53.3 & 60 & 66 & 62 \\
\hline 9 & & & & & & 7 & 3 & 17.3 & & 3 & 1 \\
\hline$* 23$ & 3 & 0 & 0 & 2 & 7 & 7 & 7 & 3.3 & 4 & 3 & 4 \\
\hline *24 & 3 & 25 & 10 & 18 & 27 & 20 & 24 & 16.4 & 11 & 23 & 16 \\
\hline 10 & & & & & & & & & & & \\
\hline$* 25$ & 6 & 5 & 6 & 4 & 7 & 7 & 7 & 4.6 & 6 & 6 & 6 \\
\hline$* 26$ & 12 & 15 & 13 & 8 & 0 & 0 & 0 & 5.2 & 9 & 9 & 9 \\
\hline$* 31$ & 3 & 0 & 2 & 5 & 0 & 0 & 0 & & 2 & 0 & 1 \\
\hline$* 32$ & 6 & 5 & 8 & 9 & 7 & 7 & 7 & 6.1 & 6 & 6 & 6 \\
\hline$* 33$ & 6 & 5 & 4 & 1 & 7 & 0 & 3 & & 6 & 3 & 5 \\
\hline$* 74$ & 0 & 0 & 0 & 0 & 0 & 0 & 0 & & 0 & 0 & 0 \\
\hline$* 36$ & 0 & 0 & 0 & 1 & 0 & 0 & 0 & & 0 & 0 & 0 \\
\hline 28 & & & & & & 13 & 7 & & & & \\
\hline$* 68$ & 9 & 5 & 8 & 11 & 0 & 0 & 0 & & 6 & 3 & 5 \\
\hline$* 69$ & 0 & 0 & 0 & 0 & 0 & 0 & 0 & & 0 & 0 & 0 \\
\hline
\end{tabular}

* The A9 specificity can be subdivided into $A * 23$ and $A * 24 ; A 10$ into $A * 25, A * 26, A * 34$, and $A * 66$; A19 into A*29, A*30, A*31, A*32, A*33, and A*74; and $\mathrm{A} 28$ into $\mathrm{A}^{*} 68$ and $\mathrm{A} * 69$.

SS, single-system disease (monostotic or polyostotic involvement, or skin only); MS, multisystem disease with or without organ dysfunction. 
Table 3. Phenotype frequencies of HLA-B allelic groups in patients with Langerhans cell histiocytosis, compared with controls

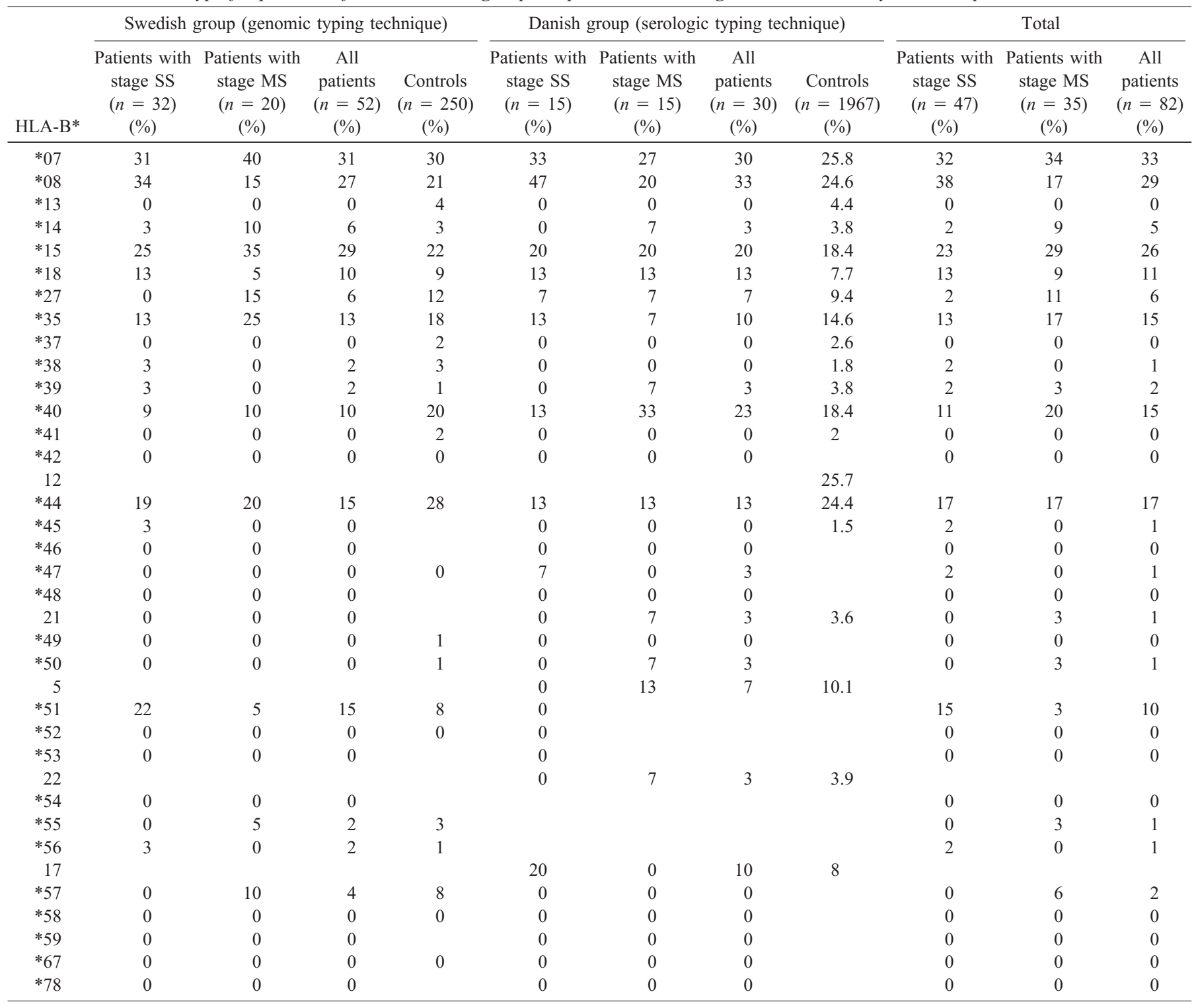

* The B12 specificity can be subdivided into B*44 and B*45; B21 into B*49 and B*50; B5 into B*51 and B*52; B22 into B*54, B*55, and B*56; and B17 into $\mathrm{B} * 57$ and $\mathrm{B} * 58$.

SS, single-system disease (monostotic or polyostotic involvement, or skin only); MS, multisystem disease with or without organ dysfunction.

serologically typed for class I compared with 250 controls, but the report does not reveal whether the increase was significant (19). These patients had LCH involving various organs, and they were not divided into subgroups. These two studies were both conducted before the classification of histiocytic disorders by the writing group of the Histiocyte Society was published in 1987 (33). One study from the United States revealed an increased frequency of HLA-Cw7 and -DR4 in 24 patients and their family controls (from different unspecified ethnic groups) (21), but the extent of the disease is not described in these patients and the results are difficult to interpret because the HLA phenotype differs in populations of different ethnic origin. In addition, an increased frequency of HLA-B7 has been reported in patients from the United Kingdom (20). In this study, $46 \mathrm{LCH}$ patients, 30 with multisystem and 16 with single-system disease, were analyzed for HLA class I and II with a serologic-typing technique and were compared with 117 controls. An increase of HLA-B7 was found in the whole group, whereas separate analysis of single- and multisystem patients showed no significant HLA association. The HLA phenotype frequencies of their control group differed from ours, with low B7 (16.2\% versus 30\%) and DR2 (19.7\% versus $33 \%$ ) frequencies. The cause of this discrepancy is not clear. The B7 frequency in their patients $(41.3 \%)$ was essentially similar to the B7 frequency in our patients (31\%). We did not find any significant differences in the phenotype frequencies of HLA-B7, -Cw7, and -DR4 or in any other HLA phenotype in our LCH patients compared with controls.

Findings suggestive of immune dysfunction in LCH include abnormal immunoglobulin levels (34), mitogen responses (35), and T-suppressor cell levels (36). Other features of LCH that are in line with the concept that immunologic mechanisms are of importance in the pathophysiology of the disease include a high frequency of spontaneous remission, as well as a tendency 
Table 4. Phenotype frequencies of HLA-DR allelic groups in patients with Langerhans cell histiocytosis compared with controls

\begin{tabular}{|c|c|c|c|c|c|c|c|c|c|c|c|}
\hline \multirow[b]{2}{*}{$\begin{array}{l}\text { HLA- } \\
\text { DR* }\end{array}$} & \multicolumn{4}{|c|}{ Swedish group (genomic typing technique) } & \multicolumn{4}{|c|}{ Danish group (serologic typing technique) } & \multicolumn{3}{|c|}{ Total } \\
\hline & $\begin{array}{c}\text { Patients with } \\
\mathrm{SS}(n=33) \\
(\%)\end{array}$ & $\begin{array}{c}\text { Patients with } \\
\text { MS }(n=21) \\
(\%)\end{array}$ & $\begin{array}{c}\text { All } \\
\text { patients } \\
(n=54) \\
(\%)\end{array}$ & $\begin{array}{c}\text { Controls } \\
(n=250) \\
(\%)\end{array}$ & $\begin{array}{c}\text { Patients with } \\
\text { stage SS } \\
(n=12) \\
(\%)\end{array}$ & $\begin{array}{c}\text { Patients with } \\
\text { stage MS } \\
(n=10) \\
(\%)\end{array}$ & $\begin{array}{c}\text { All } \\
\text { patients } \\
(n=22) \\
(\%)\end{array}$ & $\begin{array}{c}\text { Controls } \\
(n=704) \\
(\%) \\
\end{array}$ & $\begin{array}{c}\text { Patients with } \\
\text { stage SS } \\
(n=45) \\
(\%)\end{array}$ & $\begin{array}{c}\text { Patients with } \\
\text { stage MS } \\
(n=31) \\
(\%)\end{array}$ & $\begin{array}{c}\text { All } \\
\text { patients } \\
(n=76) \\
(\%)\end{array}$ \\
\hline$* 01$ & 15 & 10 & 13 & 18 & 25 & 30 & 27 & 18 & 18 & 16 & 17 \\
\hline 2 & & & & & 25 & 40 & 32 & 28 & 7 & 13 & \\
\hline$* 03$ & 33 & 5 & 22 & 17 & 50 & 0 & 27 & 24.7 & 38 & 3 & 24 \\
\hline$* 04$ & 36 & 24 & 31 & 37 & 25 & 20 & 23 & 34.2 & 33 & 23 & 29 \\
\hline 5 & & & & & & 20 & & & & & \\
\hline$* 11$ & 6 & 14 & 9 & 14 & 8 & 10 & 9 & 10.8 & 7 & 13 & 9 \\
\hline$* 12$ & 3 & 19 & 9 & 6 & 0 & 20 & 9 & 2 & 2 & 19 & 9 \\
\hline 6 & & & & & 33 & 10 & 23 & 21 & 9 & 3 & \\
\hline$* 09$ & 3 & 0 & 2 & 4 & 0 & 0 & 0 & 1.4 & 2 & 0 & 1 \\
\hline$* 10$ & 6 & 0 & 4 & 2 & 0 & 0 & 0 & 1.4 & 4 & 0 & 3 \\
\hline
\end{tabular}

* The DR2 specificity can be subdivided into DR*15 and DR*16; DR5 into DR*11 and DR*12; and DR6 into DR*13 and DR*14.

SS, single-system disease (monostotic or polyostotic involvement, or skin only); MS, multisystem disease with or without organ dysfunction.

Table 5. Presentation of the 18 patients with the HLA-DRBI*03 phenotype, the 14 patients with the deduced haplotype HLA-A*01, $B * 08$, $D R B 1^{*} 03$, and the nine patients who underwent high-resolution typing

\begin{tabular}{|c|c|c|c|c|c|c|c|c|c|c|}
\hline & $\begin{array}{c}\text { Age at } \\
\text { diagnosis } \\
\text { (y) }\end{array}$ & Sex & $\begin{array}{c}\text { Stage at } \\
\text { diagnosis }\end{array}$ & $\begin{array}{c}\text { Stage } \\
\text { at max }\end{array}$ & HLA-A & HLA-B & HLA-Cw & HLA-DR & $\begin{array}{c}\text { Deduced } \\
\text { haplotype } \\
H L A-A * 01, \\
B * 08, \\
D R B 1 * 03\end{array}$ & $\begin{array}{c}\text { High-resolution } \\
\text { typing } H L A-A^{*} 0101, \\
B^{*} 0801, \\
D R B 1^{*} 0301, \\
D Q B 1 * 0201\end{array}$ \\
\hline \multicolumn{11}{|l|}{ Swedish patients } \\
\hline & 1.7 & $\mathrm{~F}$ & $\mathrm{PO}$ & $\mathrm{PO}$ & 1 & 8 & 7 & 3 & Yes & Yes \\
\hline & 2.0 & $\mathrm{~F}$ & MO & $\mathrm{PO}$ & 1,2 & 8,44 & 5,7 & 3,4 & Yes & Yes \\
\hline & 5.7 & $\mathrm{M}$ & MO & MO & 1,32 & 8,51 & 5,7 & 3,4 & Yes & Yes \\
\hline & 7.7 & $\mathrm{M}$ & MO & $\mathrm{PO}$ & 1,24 & 8,40 & 2,7 & 3,14 & Yes & Yes \\
\hline & 8.1 & $\mathrm{~F}$ & MO & MO & 1,2 & 8,15 & 3,7 & 3,4 & Yes & Yes \\
\hline & 8.2 & $\mathrm{~F}$ & MO & MO & 2,3 & 8,15 & 3,7 & 3,13 & No & $\mathrm{nt}$ \\
\hline & 8.7 & $\mathrm{~F}$ & MO & MO & 3,11 & 7,51 & 3,7 & 3,4 & No & $\mathrm{nt}$ \\
\hline & 8.8 & M & MO & MO & 1,11 & 7,8 & 7 & 3,8 & Yes & Yes \\
\hline \multicolumn{11}{|l|}{ Danish patients } \\
\hline & 1.4 & M & skin & skin & 1,24 & 7,8 & $\mathrm{nt}$ & 2,3 & Yes & $\mathrm{nt}$ \\
\hline & 1.5 & $\mathrm{~F}$ & $\mathrm{PO}$ & $\mathrm{PO}$ & 24,32 & 8,17 & 6 & 3,7 & No & $\mathrm{nt}$ \\
\hline & 1.9 & M & $\mathrm{PO}$ & $\mathrm{PO}$ & 1,23 & 8,15 & 3 & 3,6 & Yes & $\mathrm{nt}$ \\
\hline & 2.3 & M & $\mathrm{PO}$ & $\mathrm{PO}$ & 1,2 & 8,35 & 4 & 3,7 & Yes & $\mathrm{nt}$ \\
\hline & 9.1 & $\mathrm{~F}$ & MO & MO & 1 & 8 & 7 & 3,6 & Yes & $\mathrm{nt}$ \\
\hline
\end{tabular}

MO, single-system disease with monostotic involvement; PO, polyostotic disease; MS, multisystem disease with bone and lymph node involvement; nt, not tested.

to repeated recurrences. In addition, active LCH disease may be associated with an elevated sedimentation rate and thrombocytosis (37). Finally, the relationship between smoking and pulmonary LCH has been repeatedly reported (38-41), and it has been suggested that an environmental factor such as smoking may also be involved in autoimmunity (16). An autoimmune origin of LCH has never been proved, and the present study was initiated because of our hypothesis that LCH might be an HLA-associated (auto) immune disorder.
Our result that the phenotype $D R B 1 * 03$ was significantly more frequent in single-system than multisystem LCH suggests a prognostic importance. We hypothesize that the antigen presentation via $D R B 1^{*} 03$ molecules may initiate an efficient immune response that eradicates a possible offending antigen. Interestingly, it has recently been shown that the HLA-DR subtype is associated with the prognostic subgroups in pulmonary sarcoidosis as the nonchronic form is associated with HLADR17(3) and chronic disease with DR14(6) and DR15(2) (42). 
The haplotype $H L A-A^{*} 01, B^{*} 08, D R B 1^{*} 03$ is known to be associated with the complex disease systemic lupus erythematosus, but components of this haplotype are also associated with other autoimmune diseases such as celiac disease, Graves' disease, myasthenia gravis, and insulin-dependent diabetes mellitus. In our study the deduced haplotype $H L A-A^{*} 01, B^{*} 08$, $D R B 1^{*} 03$ was found in single-system disease only. The lack of this haplotype within the group of patients with multisystem disease might lead to the hypothesis that the multisystem disease has a quite different pathogenesis. Because this haplotype is known to affect both humoral and cellular responses, it can be speculated that other HLA molecules are less efficient in presenting a possible offending antigen, or that other non-HLA molecules could be of importance in the pathogenesis of the disease.

\section{CONCLUSIONS}

In conclusion, no general association with HLA subtypes in 84 Caucasians of Nordic origin with LCH was shown. However, stratification into single-system and multisystem disease, entities with different clinical outcome, revealed that patients with single-system disease more often had the phenotype $D R B 1 * 03$ compared with patients with multisystem disease and that the deduced haplotype $H L A-A^{*} 01, B^{*} 08, D R B 1 * 03$ was found in patients with single-system disease only. Our findings suggest an immunogenetic heterogeneity in the two clinical entities of LCH and indicate that the $H L A-D R B 1 * 03$ may play a protective role against developing multisystem disease. Further studies to confirm these findings are desired.

Acknowledgments. The authors thank Beatrice Sjöberg, Anna Aldener-Cannavá, and Marie Schaffer for excellent guidance and support in the laboratory. We also thank Annelie Degard, Margareta af Sandeberg, Karin Cosic, Ulrika Kreicbergs, Ingrid Vedin, Teresia Svensson, Frida Ponthan, Lena Klevenvall, Anna-Maria Hasselgren-Häll, Stefan Larsson, Sofia Lindau, and Gun-Britt Wiklund for their valuable assistance in handling the blood samples, and Dr. Erik Forestier for complementary data of the patients diagnosed at the Department of Pediatrics at the University Hospital of Umeå.

\section{REFERENCES}

1. Carstensen H, Ornvold K 1993 The epidemiology of Langerhans cell histiocytosis in children in Denmark, 1975-1989. Med Pediatr Oncol 21:387-388(abstr)

2. Yu RCH, Morris JF, Pritchard J, Chu TC 1992 Defective alloantigen-presenting capacity of "Langerhans cell histiocytosis cells." Arch Dis Child 67:1370-1372

3. Yu RC, Alaibac M, Chu AC 1995 Functional defect in cells involved in Langerhans cell histiocytosis. Arch Dermatol Res 287:627-631

4. Willman CL, Busque L, Griffith BB, Favara BE, McClain KL, Duncan MH, Gilliland DG1994 Langerhans' cell histiocytosis (histiocytosis X) - a clonal proliferative disease. N Engl J Med 331:154-160

5. Yu RC, Chu C, Buluwela L, Chu A 1994 Clonal proliferation of Langerhans cells in Langerhans cell histiocytosis. Lancet 343:767-768

6. Willman CL, McClain KL 1998 An update on clonality, cytokines, and viral etiology in Langerhans cell histiocytosis. Hematol Oncol Clin North Am 12:407-416

7. Broadbent V, Egeler M, Nesbit ME 1994 Langerhans cell histiocytosis-clinical and epidemiological aspects. Br J Cancer 70(suppl 28):S11-S16

8. Arico M, Nichols K, Whitlock JA, Arceci R, Haupt R, Mittler Um Kuhne T, Lombardi A, Ishii E, Egeler RM, Danesino C 1999 Familial clustering of Langerhans cell histiocytosis. Br J Haematol 107:883-888

9. Bhatia S, Nesbit ME, Egeler RM, Buckley JD, Mertens A, Robison LL 1997 Epidemiologic study of Langerhans cell histiocytosis in children. J Pediatr 130:774784

10. Powis SH, Trowsdale J 1991 HLA and disease. Br J Clin Pract 45:116-120
11. Klein J, Sato A 2000 The HLA system: first of two parts. N Engl J Med 343:702-709

12. Chu T, Jaffe R 1994 The normal Langerhans cell and the LCH cell. Br J Cancer 70 (suppl 28):S4-S10

13. Corzo D, Salazar M, Granja CB, Yunis EJ 1995 Advances in HLA genetics. Exp Clin Immunogenet 12:156-170

14. Charron D 1977 Anthropology Tables in HLA: Genetic Diversity of HLA, Functional and Medical Implication. EDK Medical and Scientific International Publisher, Sèvres, pp 665-820

15. Svejgaard A $1996 \mathrm{MHC}$ and disease associations. In: Herzenberg LA, Herzenberg LA (eds) Weir's Handbook of Experimental Immunology in Four Volumes. Blackwell Scientific Publications, New York, pp 37.1-37.13

16. Shoenfeld Y, Isenberg DA 1989 The mosaic of autoimmunity. Immunol Today 10:123-126

17. McCluskey J, Peh CA 1999 The human leucocyte antigens and clinical medicine: an overview. Rev Immunogenetics 1:3-20

18. Sims DG 1977 Histiocytosis X: follow-up of 43 cases. Arch Dis Child 52:433-40

19. Tomooka Y, Torisu M, Miyazaki S, Goya N 1986 Immunological studies on histiocytosis X. I. Special reference to the chemotactic defect and the HLA antigen. J Clin Immunol 6:355-362

20. Yu RC, Chu AC 1996 Langerhans cell histiocytosis - clinicopathological reappraisal and human leucocyte antigen association. Br J Dermatol 135:36-41

21. McClain KL, Wu W-S, Pollack MS 1998 Increased HLA C7 and DR4 and altered T-cell subsets in Langerhans cell histiocytosis. Med Pediatr Oncol 31:50(abstr)

22. Lahey ME 1975 Histiocytosis X — an analysis of prognostic factors. J Pediatr 87:184189

23. Favara BE, Feller AC, Pauli M, Jaffe ES, Weiss LM, Arico M, Bucksky P, Egeler RM, Elinder G, Gadner H, Gresik M, Henter JI, Imashuku S, Janka-Schaub G, Jaffe R, Ladisch S, Nezelof C, Pritchard J 1997 Contemporary classification of histiocytic disorders. Med Pediatr Oncol 29:157-166

24. Jakobsen BK, Morling N, Platz P, Ryder LP, Thomsen M, Svejgaard A 1981 HLA-DR phenotype and HLA-B, DR haplotype frequencies in 704 unrelated Danes. Tissue Antigens 18:270-275

25. Wake CT, Long EO, Mach B 1982 Allelic polymorphism and complexity of the genes for HLA-DR beta-chains-direct analysis by DNA-DNA hybridization. Nature 300:372-374

26. Erlich HA 1999 Principles and applications of the polymerase chain reaction. Rev Immunogenetics 1:127-134

27. Olerup O, Zetterquist H 1992 HLA-DR typing by PCR amplification with sequencespecific primers (PCR-SSP) in 2 hours: an alternative to serological DR typing in clinical practice including donor-recipient matching in cadaveric transplantation. Tissue Antigens 39:225-235

28. Bunce M, Barnardo MC, Procter J, Marsh SG, Vilches C, Welsh KI 1997 High resolution HLA-C typing by PCR-SSP: identification of allelic frequencies and linkage disequilibria in 604 unrelated random UK Caucasoids and a comparison with serology [corrected and republished article originally printed in Tissue Antigens 1996;48:680-691]. Tissue Antigens 50:100-111

29. Schaffer M, Olerup O 2001 HLA-AB typing by polymerase-chain reaction with sequence-specific priers: more accurate, less errors and increased resolution compared to serological typing. Tissue Antigens 58:299-307

30. Miller SA, Dykes DD, Polesky HF 1988 A simple salting out procedure for extracting DNA from human nucleated cells. Nucleic Acids Res 16:1215

31. Vartdal F, Bratlie A, Thorsby E 1988 Immunomagnetic tissue typing offers new possibilities in cadaveric transplant donor-recipient HLA-matching. Transplant Proc 20:384

32. Willis B, Ablin A, Weinberg V, Zoger S, Wara WM, Matthay KK 1996 Disease course and late sequelae of Langerhans' cell histiocytosis: 25-year experience at the University of California, San Francisco. J Clin Oncol 14:2073-2082

33. Writing group of the Histiocyte Society (Chu T, D'Angio GJ, Favara B, Ladisch S, Nesbit M, Pritchard J) 1987 Histiocytosis syndromes in children. Lancet 1:208-209

34. Lahey ME, Heyn RM, Ladisch S, Leikin S, Neerhout R, Newton W 1985 Hypergammaglobulinemia in histiocytosis X. J Pediatr 107:572-574

35. Osband ME, Lipton JN, Lavin P, Levey R, Wawter G, Greenberger JS 1981 Histiocytosis X: demonstration of abnormal immunity, T cell histamine $\mathrm{H}_{2}$ receptor deficiency, and successful treatment with thymic extract. N Engl J Med 304:146-153

36. Shannon BT, Newton WA 1986 Suppressor cell dysfunction in children with histiocytosis X. J Clin Immunol 6:510-518

37. Calming U, Henter J-I 1998 Elevated ESR and thrombocytosis may be valuable markers of active disease in Langerhans cell histiocytosis. Acta Paediatr 87:10851087

38. Hance AJ, Basset F, Saumon G, Danel C, Valeyre D, Battesti JP, Chretien J, Georges R 1986 Smoking and interstitial lung disease. The effect of cigarette smoking on the incidence of pulmonary histiocytosis X and sarcoidosis. Ann NY Acad Sci 465:643656

39. Brauner MW, Grenier P, Tijani K, Tijani K, Battesti JP, Valeyre D 1997 Pulmonary Langerhans cell histiocytosis: evolution of lesions on CT scans. Radiology 204:497502

40. Bernstrand C, Cederlund K, Sandstedt B, Åhström L, Lundell M, Dahlquist G, Henter JI 2001 Pulmonary abnormalities at long-term follow-up of patients with Langerhans cell histiocytosis. Med Pediatr Oncol 36:459-468

41. Bernstrand C, Cederlund K, Åhström L, Henter J-I 2000 Smoking preceded pulmonary manifestations in two adults with Langerhans cell histiocytosis diagnosed in childhood. Acta Paediatr 89:1389-1392

42. Berlin M, Fogdell-Hahn A, Olerup O, Eklund A, Grunewald J 1997 HLA-DR predicts the prognosis in Scandinavian patients with pulmonary sarcoidosis. Am J Respir Crit Care Med 156:1601-1605 